Hal : $6-10$

\title{
UJI STRESS TEST MELALUI PENURUNAN SALINITAS BERBEDA UNTUK MENENTUKAN KUALITAS BENUR UDANG WINDU (Penaeus monodon Fabricius,1979)
}

\author{
KHAIRUL \\ Dosen Program Studi Pendidikan Biologi STKIP Labuhan Batu \\ Email: khairul_spi@yahoo.com
}

Diterima Oktober 2018 dan Disetujui Desember 2018

\begin{abstract}
ABSTRAK
Benur udang windu yang berkualitas baik tentunya akan meningkatkan kelulusan hidup udang yang akan dipelihara di dalam media budidaya dan tentunya akan meningkatkan hasil produksi. Namun pada saat sekarang ini sangat sulit mendapatkan benur udang yang kualitas baik. Udang yang dipelihara pembudidaya sangat tinggi tingkat kematiannya. Perlu dilakukan suatu cara yang paling sederhana untuk menentukan kualitas benur udang windu itu baik atau tidak, oleh sebab itu perlu dilakukaan uji stress test sebelum membeli benur. Melalui hasil penelitian ini nantinya para pembudidaya pembesaran udang windu bisa mengaplikasikan cara tersebut sebelum membeli benur yang akan mereka pelihara. Tujuan penelitian ini adalah untuk mengetahui kualitas benur udang windu melalui uji stress test dengan melakukan penurunan salinitas secara mendadak. Penelitian ini merupakan penelitian eksperimen dengan 4 taraf perlakuan dan diberi masing-masing 3 ulangan. Hasil penelitian yang dilakukan menunjukan kelulusan hidup tertinggi pada perlakuan A sebesar $93 \%$, diikuti perlakuan B sebesar $81 \%$, dan perlakuan $C$ sebesar $71 \%$ sedangkan yang terendah pada perlakuan A sebesar $55 \%$. Berdasarkan hasil penelitian ini, maka perlakuan A layak dijadikan pedoman untuk melakukan uji stres test sebelum membeli benur. Tingkat kelulusan hidup di atas $55 \%$ pada perlakuan $A$ dikatakan cukup tinggi, hal ini menunjukan bahwa benur udang yang telah diuji mempunyai daya adaptasi yang tinggi terhadap tekanan osmotik yang terjadi di lingkungannya tersebut.
\end{abstract}

Keyword: kualitas benur, udang windu, salinitas, uji stress test

PENDAHULUAN

Udang windu merupakan primadona komoditas hasil perikanan air payau. Pasar udang windu meliputi domestik dan eksport. Permintaan terhadap udang windu terus meningkat dari tahun ke tahun. Harga udang windu saat ini mencapai Rp. 150.000 untuk size 30 ekor per kilo.

Namun di dalam proses produksi para pembudidaya sering mengalami berbagai masalah. Mulai dari menghadapi adanya berbagai penyakit sampai susahnya mendapatkan benih yang berkualitas baik. Belum lagi mahalnya harga pakan udang saat ini. Proses keberhasilan budidaya udang dipengaruhi berbagai faktor, salah satunya kualitas benih yang baik. Benur yang baik akan meningkatkan kelulusan hidup udang yang tinggi dan hal ini tentunya akan meningkatkan hasil produksi udang.
Selama ini para pembudidaya udang kurang memahami bagaimana cara untuk mengetahui kualitas benur yang baik. Salah satu cara untuk mengetahui benur yang baik adalah dengan cara melakukan uji stress test. Uji stress test sering dilakukan adalah dengan menggunakan formalin, yakni dengan cara melakukan perendaman benur udang selama 30 menit pada formalin (37\%) $200 \mathrm{mg} / \mathrm{liter}$ air.

Penggunaan formalin sebenarnya sangat tidak ramah lingkungan dan sangat membahayakan bagi kesehatan manusia. Berdasarkan Peraturan Menteri Perikanan dan Kelautan melalui Direktur Jenderal Budidaya penggunaan formalin sudah dilarang. Sekarang ini Indonesia lagi gencar-gencarnya melaksanakan program CBIB (Cara Budidaya Ikan yang Baik), salah satunya yaitu melarang dan menggurangi penggunaan antibiotik dan 
bahan kimia berbahaya termasuk penggunaan formalin.

Berdasarkan hal-hal tersebut di atas, maka perlu dicari suatu cara yang baik untuk melakukan uji stress test dan bersifat ramah lingkungan dan aman bagi kesehatan. Melalui cara uji penurunan salinitas umpamanya. Mengingat, karena salinitas merupakan salah satu faktor pembatas (limiting factor) bagi kehidupan udang windu.

Benur udang windu yang berasal Balai Benih (hatchery) biasanya dipelihara pada salinitas yang tinggi. Salinitasnya untuk benur udang windu biasanya berkisar antara 30 - 28 ppt. Namun pada tambaktambak air payau kondisi salinitasnya lebih rendah. Maka perlu dilakukan penelitian melalui uji stress test melalui penurunan salinitas secara mendadak melalui berbagai taraf perlakuan untuk mengetahui kelulusan hidup benur udang windu. Adapun tujuan penelitian ini adalah untuk mengetahui kualitas benur udang windu dengan ketahanan hidup terbaik setelah dilakukan uji stress test.

\section{METODE PENELITIAN \\ Waktu dan Tempat}

Penelitian ini dilakukan pada tanggal 11 September 2018. Tempat penelitian dilksanakan yakni pada Pusat Pelatihan Mandiri Kelautan dan Perikanan (P2MKP) Suka Karya VI yang berada di Lingkungan $\mathrm{XX}$ Kelurahan Belawan Sicanang Kecamatan Medan Belawan Kota Medan Provinsi Sumatera Utara.

\section{Bahan}

Udang windu ukuran PL (Post Larva) 12, sebanyak 1.200 ekor. Air tawar sebanyak 100 liter dan air payau (salinitas 20 ppt) sebanyak 50 liter.

Alat

Alat-alat yang digunakan adalah refraktometer untuk mengukur salinitas pada media, stop watch digunakan untuk menentukan lama waktu percobaan; termometer untuk mengukur suhu; $\mathrm{pH}$ meter untuk mengukur $\mathrm{pH}$, DO meter untuk mengukur kelarutan oksigen (Disolved Oxygen)

\section{Wadah Penelitian}

Wadah penelitian berupa botol bekas air mineral sebanyak 12 buah dengan kapasitas $1600 \mathrm{ml}$

\section{Jenis Penelitian}

Penelitian ini termasuk jenis penelitian eksperimen karena melakukan uji coba secara langsung di lapangan. Taraf perlakuan yang akan dilakukan ada 4 dengan masing-masing 3 ulangan. Adapun taraf perlakuan yang dicobakan adalah sebagai berikut:

1. Perlakuan A (salinitas 0 ppt)

2. Perlakuan B (salinitas $5 \mathrm{ppt}$ )

3. Perlakuan $\mathrm{C}$ (salinitas $10 \mathrm{ppt}$ )

4. Perlakuan D (salinitas $15 \mathrm{ppt}$ )

\section{Prosedur Penelitian}

1. Mempersiapkan bahan dan alat penelitian

2. Mempersiapkan wadah penelitian sebanyak 12 buah

3. Melakukan sterilisasi wadah dengan mencuci dengan air bersih

4. Melakukan pengacakan wadah penelitian

5. Mengisi air sebanyak 1 liter ke dalam masing-masing wadah sesuai dengan taraf perlakuan

6. Melakukan pengecekan parameter kualitas pertama

7. Memasang aerasi pada masingmasing wadah untuk kebutuhan oksigen

8. Memasukan benur sebanyak 100 ekor per wadah

9. Benur dibiarkan selama 1 jam

10.Setelah 1 jam benur dihitung untuk mengetahui kelulusan hidupnya

11. Melakukan pengecekan kembali parameter kualitas air

12. Benur yang sudah dihitung jumlahny dimasukan ke dalam tabulasi data untuk selanjutnya dilakukan uji analisis data hasil penelitian

\section{Pengamatan dan Pengumpulan Data} Tingkat Kelulusan Hidup (Survival Rate)

Tingkat kelulusan hidup benur udang windu dapat diketahui dengan menggunakan rumus Effendie (1997) sebagai berikut :

$$
S R=\frac{N t}{N o} x 100 \%
$$

Dimana: SR = Survival Rate (\%); No = Populasi awal (ekor); Nt = Populasi akhir (ekor) 
Hal : 6 - 10

\section{Pengamatan Kualitas Air}

Pengukuran parameter kualitas air yang dilakukan meliputi: suhu, $\mathrm{pH}$, dan DO.

\section{Analisis data}

Analisi data dilakukan dengan Analisis Variansi (Anava) menurut rumus Sastrosupadi (2000) adalah sebagai berikut

$$
Y_{i j}: \mu+T_{i}+\varepsilon_{i j}
$$

Keterangan:

$Y_{i j}=$ data yang disebabkan pengaruh pemberian frekuensi ke i ulangan ke $-\mathrm{j} ; \mu$ $=$ pengaruh rata-rata umum $; \mathrm{T}_{\mathrm{i}}=$ efek yang sebenarnya dari perlakuan pada taraf ke- i ; $\varepsilon_{\mathrm{ij}}=$ efek error dari perlakuan taraf ke - i dan ulangan ke - j

Selanjutnya untuk mengetahui diterima tidaknya hipotesis yang diajukan maka dilakukan uji statistik. Menurut Bangun (1991) yakni dengan menggunakan uji $F$ dengan membandingkan nilai $F$ hitung (Fh) dengan $\mathrm{F}$ tabel ( $\mathrm{Ft}$ ) pada taraf nyata 0,05 dan 0,01

\section{HASIL DAN PEMBAHASAN \\ Tingkat Kelulusan Hidup (Survival Rate)}

Hasil penelitian menunjukan tingkat kelulusan hidup benur udang windu berbeda-beda pada setiap taraf perlakuan. Data selengkapnya dapat dilihat pada gambar histogram di bawah ini:

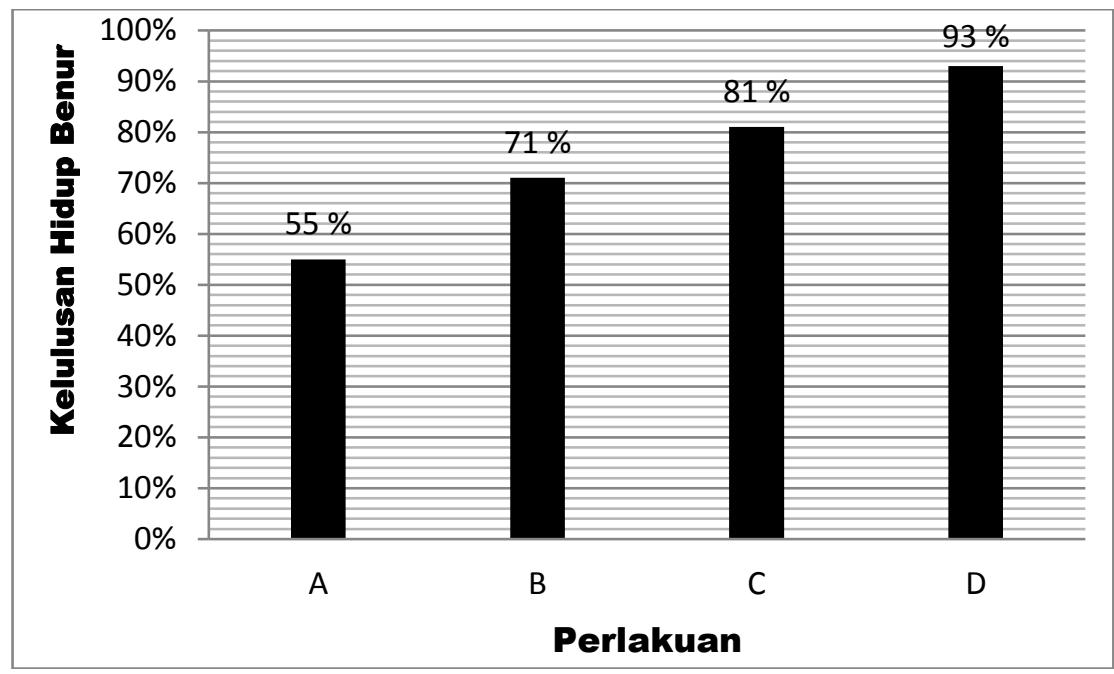

Gambar 1. Histogram Tingkat Kelulusan Hidup Benur Udang Windu Pada Setiap Perlakuan

Data hasil penelitian menunjukan bahwa rata-rata Tingkat Kelulusan Hidup (Survival Rate) benur tertinggi yakni pada perlakuan D (93\%), diikuti perlakuan C $(81 \%)$, dan perlakuan $B(71 \%)$, serta yang terendah pada perlakuan A (55\%). Hal ini dapat disimpulkan bahwa semakin rendah penurunan salinitas, maka kelulusan hidup benur akan juga akan semangkin rendah pula dan diduga karena benur udang mengalami tekanan osmotik pada media penelitian. Benur yang tidak tahan terhadap kondisi ini maka akan mati. Kondisi benur udang windu dapat diketahui berdasarkan dari hasil pengamatan yang dilakukan. Pada saat benur dimasukan ke dalam wadah langsung mengalami stress. Udang dilihat bergerak tak teratur dan bahkan melompat ke atas permukaan air, terutama yang terjadi pada perlakuan A dan B.
Saptiani dan Pebrianto (2013) menerangkan bahwa salinitas media air pemeliharaan udang berpengaruh pada tekanan osmotik. Menurut Saptiani dkk (2016) walaupun udang termasuk hewan euryhaline, yang mampu beradaptasi dengan perubahan tekanan osmose lingkungannya, namun udang juga memerlukan kondisi optimal untuk mengatur osmoregulasinya.

Perbedaan salinitas ini tentunya turut mempengaruhi tingkat kerja osmotik pada udang. Menurut Kaligis dkk (2009) bahwa perbedaan nilai tingkat kerja osmotik mengindikasikan tingkat stres berbeda yng dialami oleh udang. Lebih lanjut dijelaskan oleh Rahmawati $d k k$ (2012) bahwa salinitas berhubungan erat dengan osmoregulasi hewan air, apabila terjadi penurunan salinitas secara mendadak dan dalam 
kisaran yang cukup besar, maka akan menyulitkan hewan dalam pengaturan osmoregulasi tubuhnya sehingga dapat menyebabkan kematian.

Hasil analisis variansi menunjukkan bahwa Fh $(15,17)>$ Ft $0,05(4,07)$ berarti perlakuan uji stress test melalui penurunan salinitas secara mendadak berpengaruh sangat nyata (highly significant) terhadap kelulusan hidup benur udang windu. Berdasarkan hasil uji hipotesis yang dilakukan maka Ha diterima dan Ho ditolak

\begin{abstract}
Parameter Kualitas Air
Berdasarkan hasil pengukuran parameter kualitas air yang dilakukan selama penelitian, maka diperoleh: suhu air berkisar antara $28-30{ }^{\circ} \mathrm{C}, \mathrm{pH}$ air berkisar antara 7,6 - 7,8 dan DO berkisar antara 3,7 - 4,0 ppm. Data hasil pengukuran kualitas air selama penelitian selengkapnya dapat dilihat pada Tabel 1.
\end{abstract}

Tabel 1. Hasil Pengamatan Rata-rata Parameter Kualitas Air Selama Penelitian.

\begin{tabular}{ccccccc}
\hline \multirow{2}{*}{ Perlakuan } & \multicolumn{6}{c}{ Parameter Kuaalitas Air } \\
\cline { 2 - 7 } & \multicolumn{2}{c}{ Suhu ( $\left.{ }^{\circ} \mathbf{C}\right)$} & \multicolumn{2}{c}{ pH Air } & \multicolumn{2}{c}{ DO (ppm) } \\
\cline { 2 - 6 } & Awal & Akhir & Awal & Akhir & Awal & Akhir \\
\hline A1 & 28 & 29 & 7,7 & 7,6 & 3,9 & 4,0 \\
A2 & 28 & 29 & 7,7 & 7,7 & 3,8 & 3,8 \\
A3 & 28 & 29 & 7,7 & 7,7 & 3,8 & 3,9 \\
B1 & 28 & 28 & 7,7 & 7,7 & 3,8 & 3,9 \\
B2 & 28 & 29 & 7,7 & 7,7 & 3,8 & 3,9 \\
B3 & 28 & 29 & 7,8 & 7,8 & 3,9 & 3,9 \\
C1 & 28 & 29 & 7,7 & 7,7 & 3,8 & 3,9 \\
C2 & 28 & 29 & 7,7 & 7,7 & 3,8 & 3,8 \\
C3 & 29 & 30 & 7,7 & 7,7 & 3,7 & 3,7 \\
D1 & 28 & 29 & 7,6 & 7,6 & 3,8 & 3,9 \\
D2 & 28 & 29 & 7,6 & 7,6 & 4,0 & 4,0 \\
D3 & 28 & 28 & 7,6 & 7,6 & 3,8 & 3,9 \\
\hline
\end{tabular}

Hasil Pengamatan kualitas air selama pengukuran awal sampai akhir penelitian di atas menunjukan kondisi yang stabil, hal ini dapat dilihat karena tidak adanya perubahan parameter kualitas air secara mencolok pada semua parameter air yang diukur.

Jia et al. (2014) menyatakan bahwa berubahnya kondisi air, terutama fluktuasi suhu dan salinitas akan menurunkan imunitas udang. Suhu air yang layak untuk budidaya udang windu berkisar antara $26^{\circ} \mathrm{C}$ dan $32^{\circ} \mathrm{C}$ dan optimalnya antara $29^{\circ} \mathrm{C}$ dan $30^{\circ} \mathrm{C}$ (Poernomo, 1988).

Hasil penelitian Khairul (2017) pada parameter suhu air $28-32^{\circ} \mathrm{C}, \mathrm{pH}$ air 7,4 - 7,8 dan Oksigen terlarut berkisar 5,7 $5,9 \mathrm{ppm}$ hal ini masih menunjukan parameter air masih mendukung bagi kehidupan benur udang windu.

\section{KESIMPULAN DAN SARAN Kesimpulan}

1. Hasil penelitian menunjukan apabila semangkin rendah salinitas diturunkan maka tingkat kelulusan hidup benur akan semangkin rendah pula. Namun demikian benur yang mamput bertahan hidup menunjukan benur yang mempunyai daya tahan

tubuh yang kuat karena masih mampu bertahan hidup pada salinitas yang rendah dan tentunya menunjukan benur yang berkualitas sangat baik, karena mempunyai ketahanan yang tinggi terhadap tekanan osmotik yang ada pada lingkungan tersebut.

2. Kondisi kualitas air yang diukur selama penelitian menunjukan kondisi yang stabil karena tidak ada perubahan yang mencolok diantara semua parameter kualitas air yang diukur, hal ini tentunya sangat mendukung bagi kehidupan benur udang windu.

\section{Saran}

Disarankan kepada para pembudidaya pada usaha pembesaran udang windu untuk melakukaan uji stres test sebelum membeli benur yang akan dipelihara. Uji stres test bisa dilkukan pada kondisi salintas 0 ppt dan dilkukan selama 
1 jam. Hal ini untuk mendapatkan kualitas benur yang baik dan layak untuk dibudidayakan.

\section{DAFTAR PUSTAKA}

Effendie, I. 1997. Biologi Perikanan. Yayasan Pustaka Nusatama. Yogyakarta.

Sastrosupadi, A. 2000. Rancangan Percobaan. Praktis Bidang Pertanian. Kanisius, Jakarta.

Jia X., Wang F., Lu Y., Zhang D., Dong S., 2014 Immune responses of Litopenaeus vannamei to thermal stress: a comparative study of shrimp in freshwater and seawater conditions. Marine and Freshwater Behaviour and Physiology 47(2):79 - 92.

Kaligis, E., D. Djokosetiyanlo, dan Ridwan Affandi. 2009. Pengaruh Penambahan Kalsium Dan Salinitas Aklimasi Terhadappeningkatan Sintasan Postlarva Vdang Vannamei (Litopenaeus vannamei, Boone). Jurnal Kelautan Nasional, Vol. 2 : $101-108$

Khairul. 2017. Pemberian Dosis Probiotik Berbeda Terhadap Kelulusan Hidup
Udang Windu (Peneus monodon Fabricius). Jurnal Nukleus Vol. 5 (1): $45-50$.

Saptiani, G., dan C.A. Pebrianto. 2013. Total haemosit udang windu (Penaeus monodon) pada berbagai stadia molt dan osmolaritas. Prosiding Seminar Nasional Tahunan $X$ Hasil Penelitian Perikanan dan Kelautan Jilid II 31 Agustus 2013. Yogyakarta. Semnaskan UGM/Biologi Perikanan (BP-21): 1 - 6.

Saptiani, G., Catur A. Pebrianto, Esti H. Hardi dan Agustina. 2016. Kerentanan Udang Windu (Panaeus monodon) terhadap Vibrio harveyi pada berbagai Stadia Molt dan Osmolaritas. Jurnal Perikanan Universitas Gadjah Mada 18 (1): 19 - 25

Rachmawati, D., Johannes Hutabarat, dan Sutrisno Anggoro. 2012. Pengaruh Salinitas Media Berbeda Terhadap Pertumbuhan Keong Macan (Babylonia spirata L.) Pada Proses Domestikasi. ILMU KELAUTAN, Vol. 17 (3): 141 - 147.

Poernomo, A. 1988. Pembuatan Tambak Udang di Indonesia. Seri Pengembangan No. 7. Balai Penelitian Perikanan Budidaya Pantai, Maros, $40 \mathrm{hlm}$. 